DOI: http://doi.org/10.21698/simi.2018.ab30

\title{
ACCUMULATION OF TOXIC METALS IN AQUATIC PLANTS
}

\author{
Dorian-Gabriel Neidoni ${ }^{1}$, Valeria Nicorescu ${ }^{1}$, Ladislau Andres ${ }^{1}$, Monica Ihos ${ }^{1}$, Carol Blaziu \\ Lehr $^{2}$
}

${ }^{1}$ National Research and Development Institute for Industrial Ecology- ECOIND, Timisoara Subsidiary, 115 Bujorilor, 300431, Timisoara, ecoind.tm@gmail.com, Romania

${ }^{2}$ National Research and Development Institute for Industrial Ecology - ECOIND, 71-73

Drumul Podu Dambovitei, district 6, 060652, Bucharest, Romania

Keywords: galvanization, Lemna minor L., metals

\section{Introduction}

Water is the most important, limited and vulnerable natural resource. Water resources are open to pollution due to population growth, technological development and industrial activity growth. At present, water quality assessment is also concentrated on heavy metals because they are non-degradable, toxic and persistent in nature. Due to their properties, heavy metals can cause adverse effects on environmental components. These elements do not decompose and accumulate in plants, animals and the environment, and then enter the human body through the food chain after high enrichment in the propagation bodies. Duckweed (Lemna minor L.) is a widespread aquatic plant located in lakes, rivers, ponds and other bodies of water. Due to its small size, simple structure and morphology, rapid growth rate, short life span and environmental pollutant sensitivity, duckweed was commonly used as a hydrophilic model in ecotoxicology studies. In particular, Lemna minor L. has been reported to accumulate toxic metals and is therefore used as an experimental model to investigate the accumulation of heavy metals.

\section{Materials and methods}

The experiments were performed in 3 replicates and the arithmetic mean of the results was finally calculated. Lemna minor L. plants were placed in plastic containers of size Lxlxh $=20 \times 16 \times 6 \mathrm{~cm}$ containing zinc, copper and nickel wastewater from galvanizing plants with concentrations of: 15, 30, 50, $75 \mathrm{mg} \mathrm{Zn/1,} \mathrm{5,} \mathrm{10,} \mathrm{20,} 30 \mathrm{mg} \mathrm{Cu} / 1$ and 5, 15, $30,50 \mathrm{mg} \mathrm{Ni} / 1$. The amount of plants used was $\sim 10$ grams of wet vegetal material, sufficient to cover the entire surface of the container in a single layer of leaves. The experimental duration was 7 days at an ambient temperature of between $19^{\circ}$ and $25^{\circ} \mathrm{C}$ and the heavy metal determination in the plants and in the waters was carried out on day 0 , day 3 and day 7 .

\section{Results and conclusions}

The study shows that the Lemna minor L., accumulates considerable amounts of zinc, copper and nickel without any symptoms of toxicity. Leaf discoloration and cell death occur at plant concentrations above $2810 \mathrm{mg} / \mathrm{kg}$ d.m. in the case of zinc, $823 \mathrm{mg} / \mathrm{kg}$ d.m. in the case of copper and $\sim 400 \mathrm{mg} / \mathrm{kg} \mathrm{d}$.m. in the case of nickel (Figure 1). If a comparison is made between the quantities of the three metals accumulated by the plant, it is observed that it has an increased affinity for zinc, followed by copper and then nickel. 


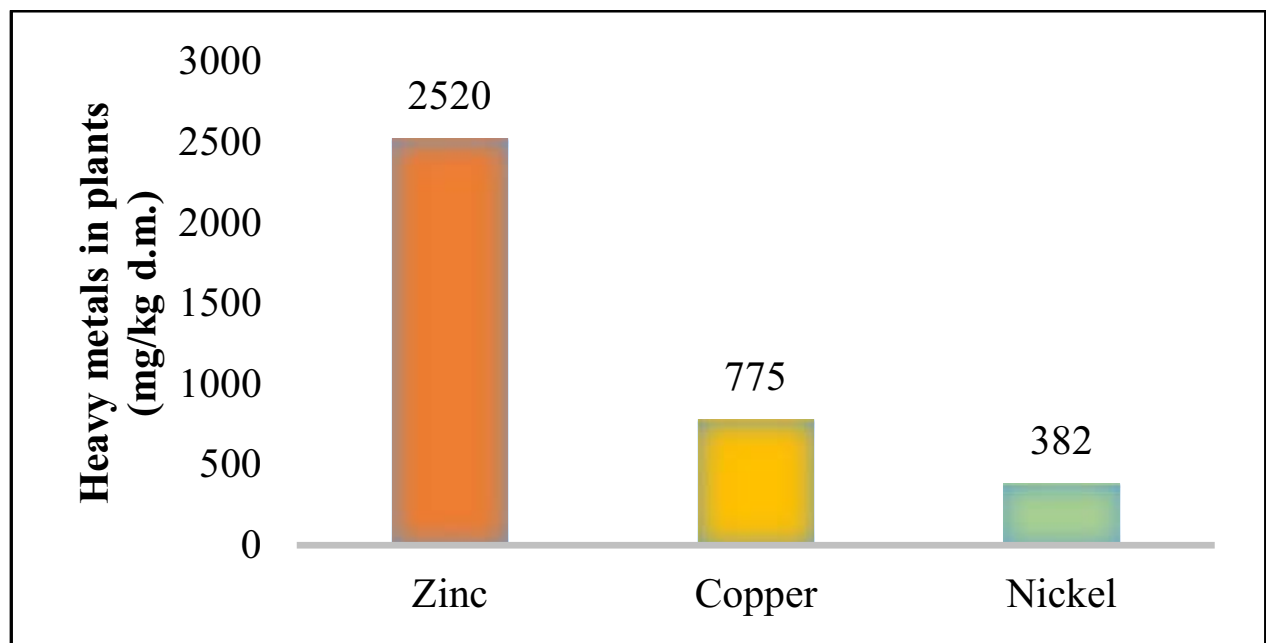

Figure 1. The maximum amount of metal accumulated in plants

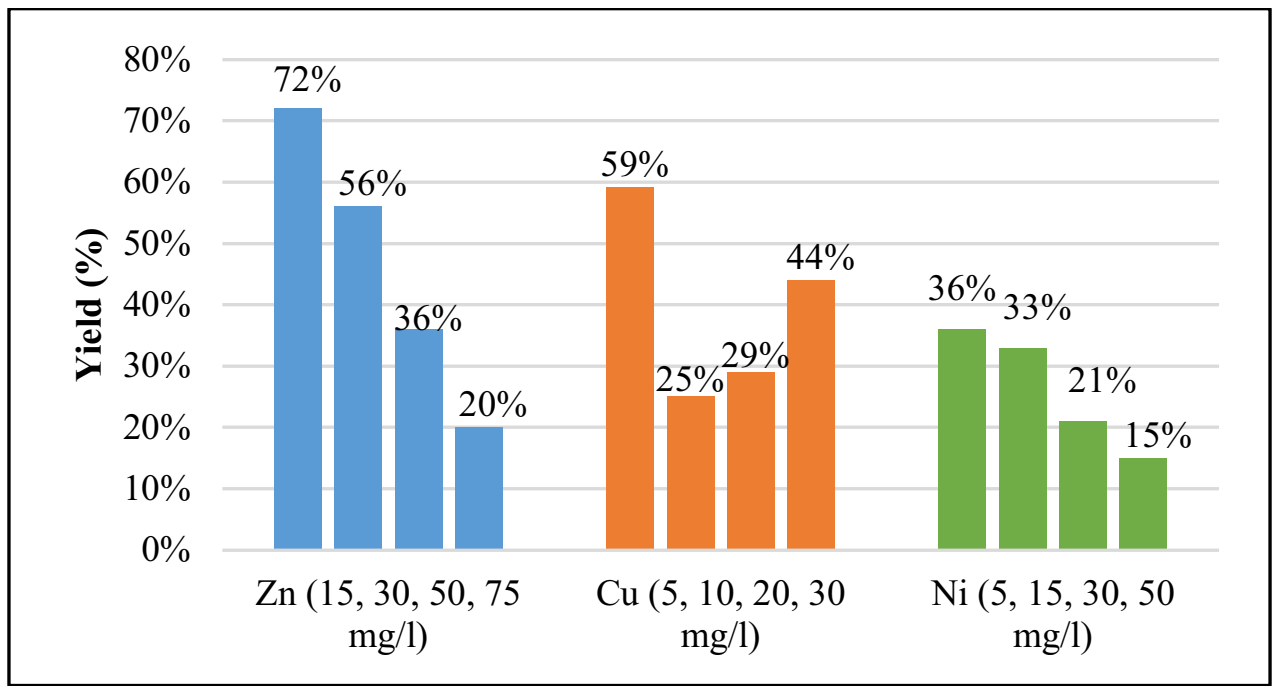

Figure 2. Percentage of purification yield

The best purge yields are obtained at the lowest initial concentrations, namely: $72 \%$ at the initial concentration of $15 \mathrm{mg} \mathrm{Zn} / 1,59 \%$ at the initial concentration of $5 \mathrm{mg} \mathrm{Cu} / 1$ and $36 \%$ at the initial concentration of $5 \mathrm{mg} \mathrm{Ni} / 1$ (Figure 2). The explanation is that it is reached a limitation of the degree of bioaccumulation of $\mathrm{Zn}, \mathrm{Cu}, \mathrm{Ni}$ in the plant, under the conditions of the experiment (volume of water, volume and geometry of the experimental containers, the initial quantity of the plant). Regarding the speed of the accumulation processes, it is noticeable that they are greatly increased in the first three days, then decrease over the next four days. From this it can be concluded that for an efficient treatment of wastewater loaded with heavy metals, especially those loaded with zinc, copper and nickel, the experimental duration should be between three and four days, where the accumulation intensity is the highest.

\section{Acknowledgements}

The present research was financially supported by the Romanian Nucleu Programme, Project PN 18050302 . 